\title{
Cicada Killer, Giant Ground Hornet, Sphecius hogardii (Latreille) and Sphecius speciosus (Drury) (Insecta: Hymenoptera: Sphecidae) ${ }^{1}$
}

Lionel A. Stange ${ }^{2}$

\section{Introduction}

Cicada killers, or giant ground hornets, are among the largest wasps in Florida (up to $40 \mathrm{~mm}$ in length). They are conspicuous insects, since the males are territorial and will butt or grapple with intruders including other males. There are 22 species of Sphecius Dahlbom in the world and all hunt cicadas as far as is known. Two of four Nearctic species of Sphecius occur in Florida. The females of the common Florida species, Sphecius speciosus (Drury), hunt Tibicen spp. cicadas and can dig 4-foot burrows in the ground with several branches and cells. The provisioning with cicadas is nearly specific to Sphecius in the family Sphecidae, but is known in a few other sphecids such as Liogorytes joergenseni (Brethes) from Argentina (Bohart and Stange 1976).

\section{Biology}

This biology is based on Sphecius speciosus. Lin (1966) observed copulatory habits in these wasps. Usually, copulation was initiated while the wasps were on the ground, with the male grasping the female from behind. Then the wasps would fly out with the female dragging the usually smaller male. Their heads are diametrically opposed while in flight. However, both wasps used their wings in flight which can last up to 45 minutes.

The fertilized female begins the reproductive cycle by making burrows 0.3 to 1.2 meters in length, with numerous branches and cells. The front legs rake the soil which is pushed out behind the female with her hind legs, resulting in a large dirt mound. The burrows are left open during provisioning and may never be closed. However, the cells are carefully closed when completed. From one to four cicadas per cell are deposited depending on the size of the cicada.

The female paralyzes the host by stinging the membrane at the base of the foreleg, then carries the cicada venter to venter by dragging or flying to the nest. One egg is placed on the last cicada in each nest. Apparently, the mother wasp can determine the sex of the egg and places the female egg with the more abundant provisions. Lin and Michener (1972) saw up to four females of $\mathrm{S}$. speciosus provisioning a single nest simultaneously which may indicate a step toward sociality.

1. This document is EENY295, one of a series of the Entomology and Nematology Department, Florida Cooperative Extension Service, Institute of Food and Agricultural Sciences, University of Florida. Original publication date June 2003. Revised January 10, 2005. Visit the EDIS Web Site at http://edis.ifas.ufl.edu.

2. Lionel A. Stange, Division of Plant Industry, Florida Department of Agriculture and Consumer Services, Gainesville.

The Institute of Food and Agricultural Sciences (IFAS) is an Equal Opportunity Institution authorized to provide research, educational information and other services only to individuals and institutions that function with non-discrimination with respect to race, creed, color, religion, age, disability, sex, sexual orientation, marital status, national origin, political opinions or affiliations. U.S. Department of Agriculture, Cooperative Extension Service, University of Florida, IFAS, Florida A. \& M. University Cooperative Extension Program, and Boards of County Commissioners Cooperating. Larry Arrington, Dean 


\section{Key to Species of Sphecius in Florida}

1. Body predominately rust orange color with mostly black antennae and last few segments of the abdomen black . . . . . Sphecius hogardii (Latreille)

$1 '$. Body predominately black with first three abdominal segments with large yellow spots; legs, mesoscutellum, and part of vertex rust orange color . . ... Sphecius speciosus (Drury)

\section{Sphecius hogardii (Latreille)}

This is a Caribbean species known from the Florida Keys (Key West) and here newly recorded from Lover's Key, Lee County, Florida, 16 July 1999, C. Porter and L. Stange, collectors. It appears to be uncommon in Florida and nothing is known of its host preferences. The rust orange coloration is distinctive. However, the black on the abdomen is variable. The Bahama populations lack the black coloration (subspecies bahamas Krombein)

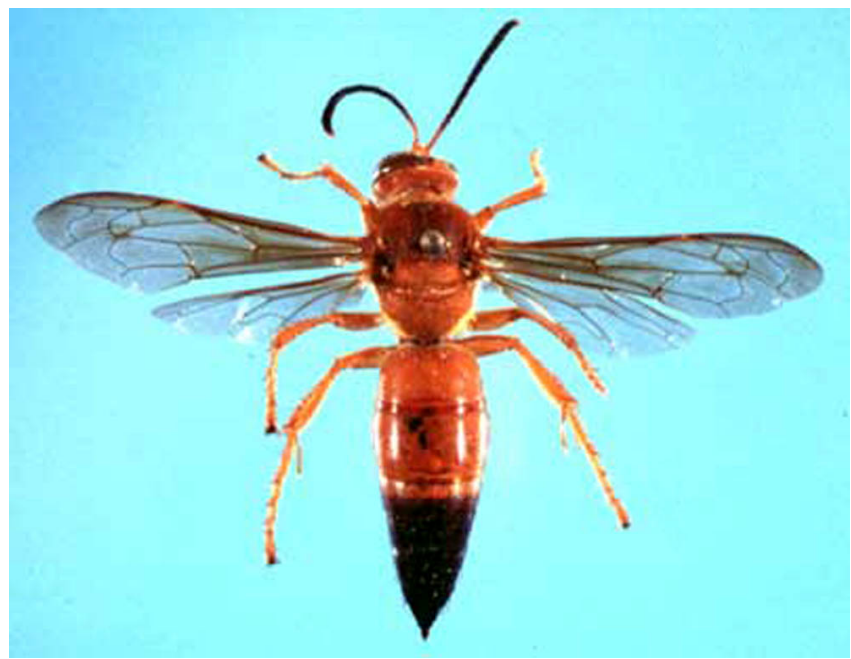

Figure 1. Sphecius hogardii (Latreille), a cicada killer wasp. Credits: Division of Plant Industry

\section{Specius speciosus (Drury)}

This wasp is widely distributed east of the Rocky Mountains and south into Mexico. Sometimes common locally in Florida especially during the summer months where many wasps may nest together gregariously. Human encounters with this giant wasp are only seemingly dangerous since usually it is the stingless male which is the aggressor. The four foot burrows may have more than 16 cells which contain one to two cicadas each of many species of Tibicen. The wasps are parasitized by sarcophagid flies (Senotainia trilineata (Wulp); Metopia argyrocephala (Meigen)) and possibly mutillid wasps.

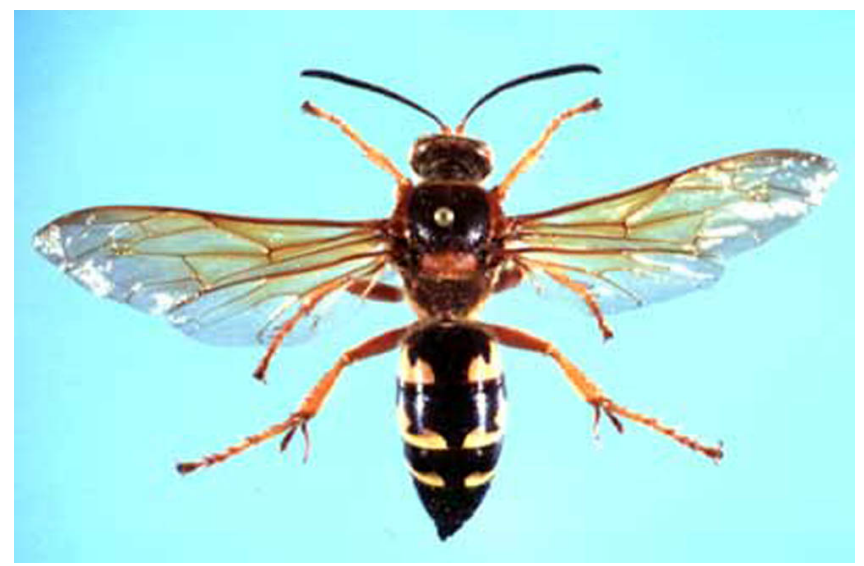

Figure 2. Sphecius speciosus (Drury), a cicada killer wasp. Credits: Division of Plant Industry

\section{Management}

Cicada killers are usually considered beneficial insects since they destroy plant feeding cicadas. Also, they rarely sting except when the females are handled. However, under certain circumstances such as when elderly persons or young children are present in the breeding areas one may want to discourage their presence. This can be done by eliminating or reducing the breeding area which usually consists of exposed, sandy soil. This area can be mulched or covered with grass. Labeled insecticides can be applied to the nesting sites to kill the wasps.

\section{Selected References}

\section{Bohart RM, Stange LA. 1976. Liogorytes} joergenseni (Brèthes), a cicada killer in Argentina. Pan-Pacific Entomologist 52: 313.

Bohart RM, Menke AS. 1976. Sphecid wasps of the world - a generic revision. University of California Press. 695 p.

Dambach CA, Good E. 1943. Life history and habits of the cicada killer (Sphecius speciosus) in Ohio. Ohio Journal of Science 43: 32-41. 
Davis WT. 1920. Mating habits of Sphecius speciosus, the cicada killing wasp. Bulletin Brooklyn Entomological Society 15: 128-129.

Eiseley L. 1976. The coming of the giant wasps. Defenders of Wildlife. pp. 152-157.

Evans HE. 1966. The comparative ethology and evolution of the sand wasps. Harvard University Press, Cambridge, xvi $+526 \mathrm{p}$.

Lin N. 1963. Territorial behaviour in the cicada killer wasp, Sphecius speciosus (Drury). I. Behaviour 20: 115-133.

Lin N, Michener CD. 1972. Evolution of sociality in insects. Quarterly Review of Biology 47: 131-159. 